\title{
工場の立地とその敷地嫢模・建築密度 との関係について
}

伊 藤 喜 栄

\section{1 はしがき}

一般に「工場の敷地規模は個々の工場の業種業態などによってことなり，い ずれの工場にも共通した工場敷地規定を算出する法則は現在皆無である」とさ れている。そのために，今日各種地域計画策定に当っての，これらに関する原 単位としては，既存の工場についての経験值・平均值の用いられる場合が多

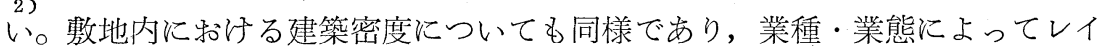
アウトが基本的に相異するために，一概には決め難い性質のものである。した がってこの数值もまた，既存の工場から得られた結果をもって一応の基準とす る方法が一般には行われている。

これら敷地規模・建築密度等については，従来事例的にしか得ることができ なかったが, 昭和36年度工業統計調査に付带して用地調查が取り上げられ，これ には従業者 30 人以上の事業所についての敷地面積・建築面積がもれなく調査さ れているために, 今後用地に関する原単位として,この結果から算出された平均 值がしばしば利用されるものと思われる。しかしながら，井関弘太郎も指摘す るごとく「地域別・業種別に吟味しない限り，全国的数値を個々の地域に単純 に利用することは危険」であろら。なぜならば，現実の地表空間には各々地点 ・地域ごとに固有の位置価值を備えているのであり，それと関連した土地供給 の弾力性とあいまって，土地利用強度ないし密度に地域差をもたらすはずたかか らである。つまり「大都市圈（一般には位置価值が相対的に高く，土地供給の弾力性が 相対的に小さい）の工場の土地利用之, 田園地帯, 国土の周辺地域（一般には位 置価值が相対的に低く, 土地供給の弾力性が相対的に大きい）の工場の土地利用とは, その密度を晎にする筈である。大都市圈に散在，あるいはその中の特定地区に 集積する工業はそれぞれの位置の価值に相応した業種と土地利用強度と示して いなければならない」（カッコ内筆者）と考它られるのである。

このよらな土地利用強度の地域的特性については，すでに春日茂男が単位敷 地面積当りの付加価值額 $\doteqdot$ 地代を指標として優れた分析を加えているが，土地 
利用強度ないしは密度の地域差は, より景推的な指標ではむるけれども敷地規 模, 建築密度によっても把觉ることが可能と考光られる。つまり，位置洒值の 高い, したがって土地供給の弾力性に乏しい地点・地域に立地する工場は, 確 率的に見て敷地規模が小さく，建築密度が高いことが，逆に位置価值の低い， したがって土地供給の弾力性が大きい地点・地域に立地する工場は，敷地規模 が大きく，建築密度が低いということが予想されるのである。

小稿はかかる予想を全国及び中京都市圈について吟味しょうと試之たもので ある。この場合，前者に拈いては大都市圈と国土の周辺地域との関係が，後者 に扮いては大都市圈の核心部分とその外縁地域との関係が問題として意識され ていることは言うまでもない。

\section{2 集積度の地域的特性}

前述のごとく, 土地利用強度の高低は, 位置価値及び土地供給の弾力性と密 接な関係を持っているのであり，位置価值が高く，土地供給の弾力性が小なる 地点・地域に扔いて高く, 逆の場合低い。ところで位置価值を「特定位置の利 益の享受に外ならない」とするならば，多くの症業にとって有利な条件を提供 する「都心部に近い交通接合地点近傍などに扔ける固有の位置と結びついた土 地」に扔いてもっとも高く, 限られた土地をめぐって立地の競合が起る結果, 工業集積の度合も最高となると考兄られる。このような地点を中心として「漸 次周縁部に至るに従って位置の価值が減ずると共に面積的にも土地供給の弾力 性が増すため立地競合の度合が緩和され」集積度も減少することが予想される。 從って, 土地利用強度の一端として敷地規模・建築密度等を見る場合, その前 提として地域の集積度（位置価値の指標としての）を測定して括く必要がめる。

集積の概念及びその測定法についてはな陉諸説があるが，ここではその相対 的な地域差が算出できれば一応目的を達するわけであるから，単位面積当りの 工場数と，単位面積当りの付加価值額との相関から，その度合を求めてみた。 第 1 図(全国)，第 2 図 (中京)がそれである。雨図とも中の番号は後に述べる地 域（都道府県また怄市町村等）の番号と一致している。また図中の点線Xは単 位面積当り工場数の平均值を，Yは同じく単位面積当り付加価值額の平均值を 示している。従って, 両図ともIの部分はこれらいずれの平均值をも上迴って 牤り,ここに分布する諸地域の集積度は, 他の部分に分布する諸地域に比べ高い ことを示している。一方亚の部分はいずれの平均值をも下迴って和り，この部 分にある諸地域の集積度は相対的にもっとも低い。平均值の一方のみが上迴っ ているIIの部分の諸地域は，それらの中間の集積度を示すとみなされる。これ 
らのらち, Yについての 又上廻っているII-Aの 部分のものは, 工場数に 比べ付加洒值額が大きく, 傾向として大規模生産に よる集積が優位を占めて いると考えられ，Xにつ いてのみ上迴っているII 一Bの部分のものは，工 場数に比べ付加価值額が 少なく，傾向として社会 的集積が支配的と見るこ とがでさよう。このよら な基準から地域の類型化 を試るならば次のごとく である。ただしI，亚に ついてはその (集積の) 程

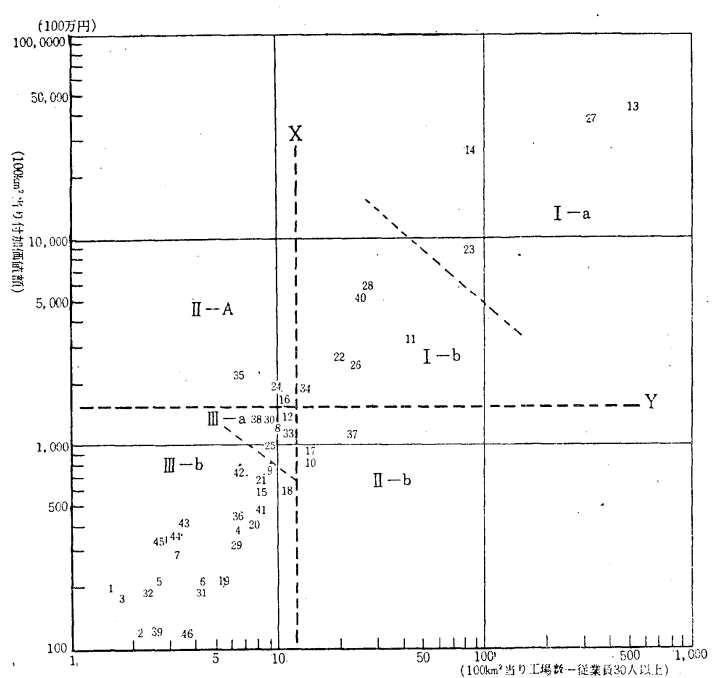
度にしたがって，図示の ごとく $\mathrm{a}, \mathrm{b}$, の二つの グループに細分すること にする。

\section{[全 国]}

$I$ - a …113)東京, (14)神奈 川, (23)愛知, (27) 大阪

$I-b \cdots$ (11)埼玉，(22)静岡， (26)京都，28)兵庫， (34)広島, (40)福岡

II-A…16)富山, (24)三重, (35)山口

II-B…群馬，(17)石川， (37)香川

III- a …8荻城, (12)千葉, (25)滋賀，30和歌 山, (33)岡山, (38)
． 第1図 都道府県の集積:度

註）通産省：「工業用地統計表」1963より作成。

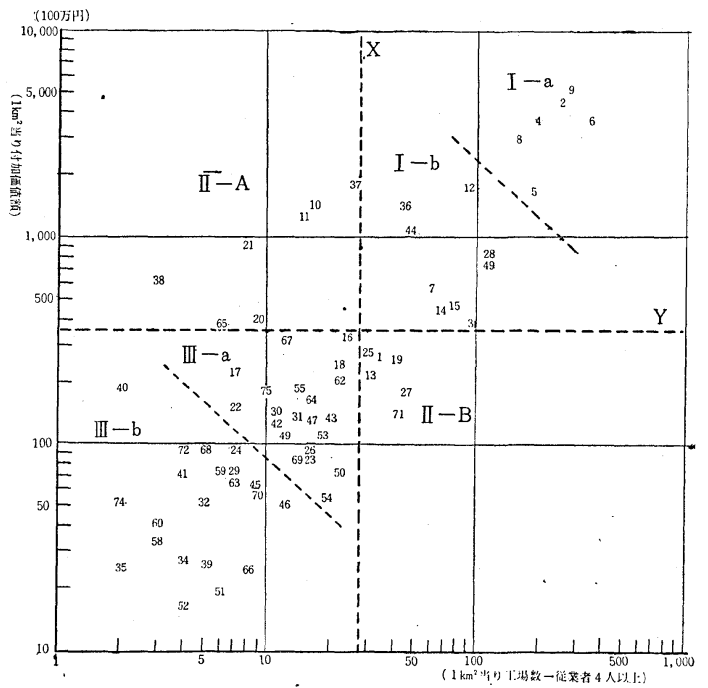

第 2 図中京都市圈に扮ける区・市・町・村の集積度 註）愛知県統計課資料より作成。 
带瑗

III- $b \cdots$ (1)北海道, (2)青森, (3)岩手, (4)宮城, (5)秋田, (6)山形, (7)福島, (9)栃木, (15)新 潟, (18)福井, (19)山梨, (20)長野, (21)岐阜, (29)奈良, (31)鳥取, 32島根, (36)徳島, (39) 高知, (41)佐賀, (42)長崎, (43)熊本, (44)大分, (45)宮崎, (46)鹿児島

[中 京]

I- - ‥(2)名古屋市東区, (4)司西区, (5)同中村区, (6)同中区, (8)同瑞穗区, (9)同熱田 区

I- - ‥(3)同北区, (7)同昭和区, (12)同南区, (14)一宮市, (15)瀬戸市, (29)尾西市, (36)東春日 井郡旭町, (444西春日井郡新川町, (49)葉栗郡木曽川町

II-A…110名古屋市中川区, (11)同港区, (20)㺫谷市, (21豊田市, 377西春日井郡枇杷島町, (38)同豊山村, 66知多郡大府町

II-B …11)名古屋市千種区, (13)岡崎市, (19)碧南市, (25)常滑市, 227江南市, (72)碧海郡高浜 町

III- $\mathrm{a}$ …16半田市, (17)春日井市, 18津島市, (22)安城市, (23)西尾市, 26守山市（現名古屋 市守山区), (30稲沢市, (31)愛知県鳴海町 (現名古屋市緑区), (42)西春日井郡春 日村，(43)同清洲町，(47)丹羽郡岩倉町，(49)中島郡祖父江町，50同平和町，(53)海部 郡甚目寺町, (53)同大治村, (55)同蟹江町, 62同佐織町, 64)知多郡東浦町, 67同大 高町, 69同横須賀町, (75)同碧海郡知立町

III- $\mathrm{b}$-.244犬山市, (29)小牧市，32愛知郡豊明町，(33)同東郷村，(34)同日進町，(35)同長久手 村，(39)西春日井郡北里村，(40同師勝村，(41)同西春村，(45)丹羽郡大口村，(49)同扶 桑町，51海部郡七宝村，(52)同美和町，56同十四山村，57同飛島村，58同弥富 町, (59)同佐屋町, 60同立田村, 61同八開村, 632知多郡阿久比町, 66同有松町, (68)同上野町，(70同知多町，(72)碧海郡桜井町，(73)同上郷町，(74)同高岡町，(76)同”之 ツ美村 (現岡崎市), (77)西加茂郡三好町

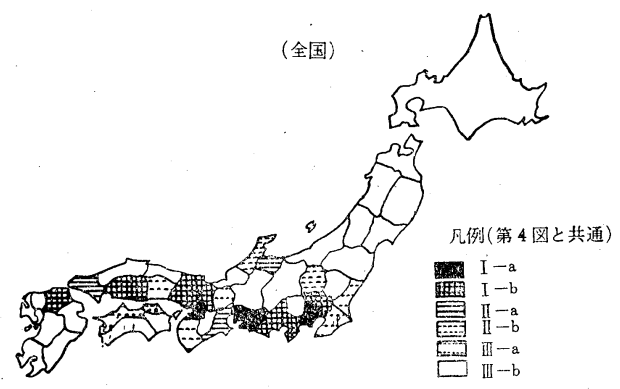

第 3 図 集積度による地域類型 註）第 1 図より作成。

全国の場合第 3 図を参照する までもなくI，II，及びIII-a 等, 比較的集積の度合が高い都 道府県は，いわゆるベルト地帯 にその大半が集中し，外にほわ ずかに北陸の工業地域があげら れるのみである。これをさらに 詳細に検討するならば，Iー は京浜·中京・阪神等, 大工業地 带の主要部を持つ都府県に限ら れて打り，とくに京浜・阪神の 中核部分に当る東京・大阪の集積度は著しく高い。I-bには京浜・阪神の外 
延部，瀬戸内 · 北九州工業地带の中心部を占める府県が，II一Aには中京·北 九州・瀬戸内の外延部の諸県が，II一B，III一 a にはさらにその周辺の諸県が 分布し，その結果として東関東から北九州をつなぐ高集積地帯が形成されてい る。な打北陸の工業地域はこの図からも明かなように集積の性格が全く対照的 な二つの地域の複合体と見ることがでさよう。以上のような高集積地域を取り 囲んで亚一b 諸県が分布し, 東日本に括ける中央高地・東北・北海道, 西日 本に抢ける山陰・南四国・南九州等，いわゆる「国土の周辺地域」，低集積地 域を構成しているのである。

このような圈構造（それはきわめて歪の大きいものであるが）は，中京都市圈の 場合にも認めることができる (第 4 図)。I中村区・熱田区・西区・瑞穂区等を核心と して, 第 2 圏にはIII - b の昭和・南・北の 各区及び新川町が，第 3 圈にはII-Aの港 区・中川町·大府町，あるいはII-Bの千 種区等が配置されている。第 4 圏に相当す るのはIII一 - の春日井市・守山市・鳴海町 ·東浦町 · 横須賀町 - 蟹江町 · 大治村 - 甚 目寺町・清洲町・春日村・稲沢市等であり， さらにその外縁にIII-bの小牧市・師勝町 ·北里村 $\cdot$ 西春村 $\cdot$ 美和町 $\cdot$ 七宝村 $\cdot$ 上野 町・知多町・阿久比町・豊明町 $\cdot$ 日進町 東郷村・長久手村等が分布している。そし て，このような圈構造を取り囲を形で，一 宮 ·尾西 · 瀬戸 ·豊田 · 岡崎 · 刈谷 · 碧南 ・常滑等, 比較的集積度の高い衛星工業都 市が配殖されているとも見ることができよ

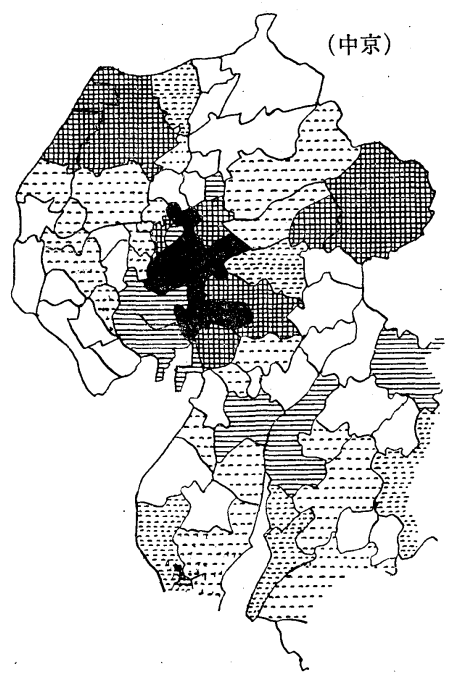

第 4図 集積度による地域類型 註）第 2 図より作成。 ら。

\section{2 集積度の地域的特性と敷地規模・建築密庋との関係}

一般に敷地規模の原単位は一事業所当りの敷地面積の形で示されることが多 いが，この場合，事業所の経営規模による敷地面積の格差が覆いかくされてし まらららみがある。したがって敷地利用度の測定といら目的のためには必ずし も適当な指標とはなり爷ない。故にここでは從業者 1 人当りの敷地面積をもっ て敷地規模の指標としたい。もちろんこの方法によっても経営規模による敷地 
面積の格差を完全には修正し得ないが，前者の方法に比べ，その歪みをかなり 是正することができる。また敷地利用の度合測定といら面からも，その逆数， つまり敷地面積に対する從業者密度をとれば，ほぼ単位敷地面積当りの労働投 入量を示すと見ることができるからである。なお建築密度については（事業所

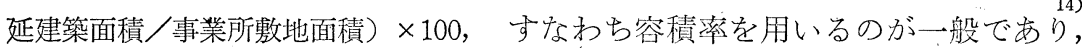
この場合もとれに従った。

ところで, これらの全国に拈ける平均値は, 從業者 1 人当り敷地面積の場合 $103 \mathrm{~m}^{2}$, 容積率の場合 $32.6 \%$ となる。前者の最大は秋田県の $300 \mathrm{~m}^{2}$, 最小は東 京都の $48 \mathrm{~m}^{2}$ ， また後者の最大は東京都の $53.1 \%$ ，最小は秋田県の $12.5 \%$ であ り，両指標の間には逆の相関関係があることがわかる。な特，中京 (愛知県) の 場合，前者の平均值は $102 \mathrm{~m}^{2}$, 後者の平均值は34.8\%で，前者の場合僅かに全 国の值を下迴り，後者については若干高い比率を示す。また前者の最大は東郷 村の $980 \mathrm{~m}^{2}$ ，最小は春日村の $42 \mathrm{~m}^{2}$ ，後者の最大は中村区の $13.4 \%$ ，最小は長 久手村の $9 \%$ となり，全国についての場合より地域間の較差が著しく大きい。 次にこれらが各地域の 集積度に応じてどのような特性值を示すかは第 5 図 (全国)，第 6 図 (中京) により明かとなる。すなおち，ごく一般的には従䒹
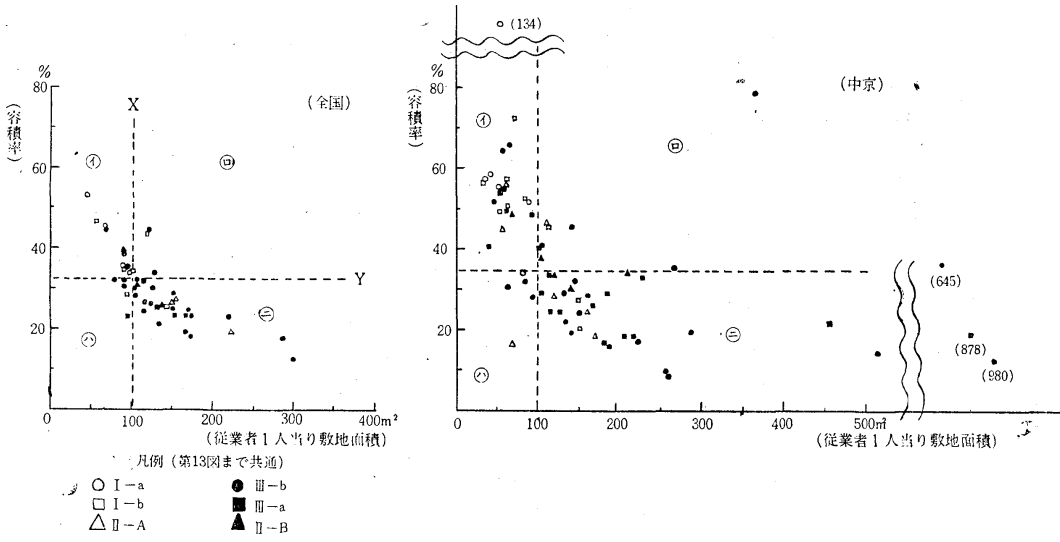

第 5 図 集積度と敷地規模・建築密度（全国）

第 6 図 集積度と敷地規模・建築密度（中京）

註）ともに通産省工業用地統計表より作成。

者 1 人当りの敷地面積が小さい地域ほど容積率が高いが，このよらな傾向を示 すのは概ね集積度の高い地域であり，集積度の低い地域では従業者 1 人当りの 敷地面積も大きく，容積率は低いといら結果が得られる。たとえばこれらの図 を(1)…(従業者 1 人当り敷地面積については平均を下迴るが容積率では平均を凌駕する), 


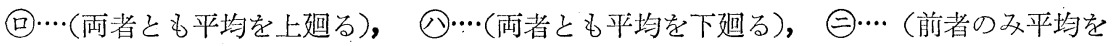
上迴り，後者は平均に達しない）の四つの部分に分けた場合，(1)の部分に分布す

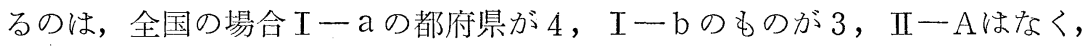
II-Bが 1, III- $\mathrm{a}$ もなく, III- $\mathrm{b}$ のものが 3 となるのに対し, (1)と対照的な

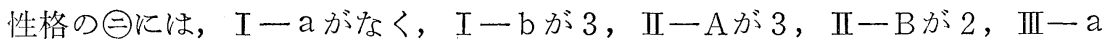
が 5, III-bが16となり，(1)の部分には压倒的に集積度の高い地域が，きの部 分では压倒的に集積度の低い地域として分布する結果となっている。しかも (1) の部分の $I-a, I-b$ とIII- $b$ とでは， $I-a ， I-b$ 等が III- $b$ 上りも左

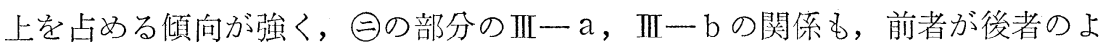

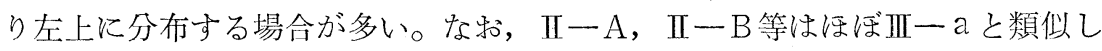
た位置を占めているが，これら両者の間ではIIーBの方がより左上に分布する 傾向を示している。

第 6 図 (中京) の場合，第 5 図（全国）の場合に比べ，数值のばらつきの程度 が甚だしく，それだけ例外的な性格の市町村が多く含まれていることを物語っ ているが，基本的な傾向に招いては全国の場合と類似している。すなわち(1)

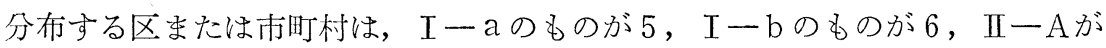

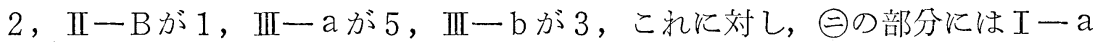

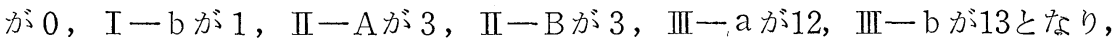
集積度の高い地域の工場は「従業者 1 人当りの敷地面積が小さく, 容積率は高 い」という場合が多く，集積度の低い地域に立地する工場の多くは「從業者 1 人当りの敷地面積が大きく，容積率が低い」といら対照的な性格を示す。(1)

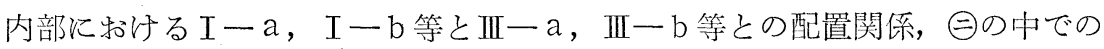
III一 $\mathrm{a}$ 之III- $\mathrm{b}$ との配置関係も, 全国の場合程はっきりした形をとらないけれ ぞも，ょり左上により集積度の高い地域が，ょり右下により集積度の低い地域 が分布するという傾向は，この場合にもやはり認めることができよう。

な执，(1)少数ながら認められるIII-

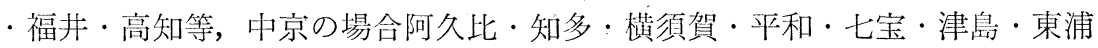
等, 多くは在来工揱を基盤として発展して来た軽工業が主力となっている地域 であり, 逆に右下の曰に認められる少数の $\mathrm{I}$ 一 b は, 全国の場合の福岡, 中京 の場合の南区・旭町等, 近代的な重化学工業, 穼業を主とする地域に限られ る。このことは, 敷地規模, 建築密度等の分析に当っても, 単に業種別・地域 別の吟味だけでは不十分であり，より詳細には歴史的な考察をも必要とするこ とを暗示している。 


\section{4 敷地規模・建築密度の業種的特性と地域的特性}

前節の考察によれば，工場の敷地規模・建築密度等は，その立地と密接な関 係があり，「一般に集積度の高い地域にある工場は，そうでない地域のものに 比べて従業者 1 人当りの敷地面積が小さく, 容積率が高い」といらことにな る。しかしながら，このよらな工場の敷地規模・建築密度等は，第 1 表のごと く業種によっても著しい開きが認められる。たとえば全国の場合, 彷業者 1 人 当り敷地面積の最大值 $500 \mathrm{~m}^{2}$ (石油製品・石炭製品製造業) は，最小值 $16 \mathrm{~m}^{2}$ (出版 ・印刷・同関連産業）の約31倍，容積率の最大値195\%（出版・印刷・同関連産業）

第 1 表 敷地規模・建築密度の業種的特性

\begin{tabular}{|c|c|c|c|c|c|c|c|}
\hline & & \multicolumn{3}{|l|}{ 全 } & \multicolumn{3}{|c|}{ 京 } \\
\hline & & $\begin{array}{l}\text { 従業者 } 1 \text { 人当り } \\
\text { 敷地面積 }\end{array}$ & & 積 率 & $\begin{array}{l}\text { 䢨菜者 } 1 \text { 人当り } \\
\text { 敷地面積 }\end{array}$ & 容 & 積 率 \\
\hline 褩＼cjkstart造＼cjkstart業 & 計 & $103^{m^{2}}$ & & $32.6 \%$ & $102^{\mathrm{m}^{2}}$ & & $34.8 \%$ \\
\hline 食＼cjkstart料 & 品 & 88 & & 41.8 & 71 & & 51.2 \\
\hline 緎 & 維 & 95 & & 41.3 & 88 & & 46.3 \\
\hline 衣 & 服 & 24 & & 56.9 & 40 & & 42.1 \\
\hline 木材 · 木製 & & 121 & & 24.8 & 84 & & 35.5 \\
\hline 家 具装 備 & & 52 & & 48.0 & 66 & & 34.6 \\
\hline パルプ・ & 紙 & 171 & . & 25.4 & 190 & & 21.7 \\
\hline 出版 · 印 & 刷 & 16 & & 195.0 & 18 & & 97.0 \\
\hline 化 & & 221 & & 21.6 & 188 & & 21.8 \\
\hline 石油・石炭製 & & 500 & & 8.8 & 192 & & 28.4 \\
\hline ゴ ム 製 & & 46 & & 45.5 & 114 & & 22.2 \\
\hline 皮 龩 製 & 品 & 59 & & 42.2 & $\mathrm{x}$ & & - \\
\hline 筥＼cjkstart業 土 & 石 & 125 & & 30.8 & 94 & & 40.8 \\
\hline 鉄 & 鋼 & 161 & & 24.8 & 194 & & 22.2 \\
\hline 非 鉄 金 & 属 & 275 & & 20.2 & 174 & & 26.1 \\
\hline 金 属 筊 & 品 & 58 & & 45.7 & 54 & & 47.3 \\
\hline 機 & 械 & 82 & & 35.1 & 110 & & 31.9 \\
\hline 電＼cjkstart気＼cjkstart機 & 器 & 47 & & 38.9 & 63 & & 39.1 \\
\hline 輸＼cjkstart送＼cjkstart機 & 器 & 109 & & 39.1 & 129 & & 25.5 \\
\hline 精＼cjkstart密＼cjkstart機 & 器 & 57 & & 37.0 & 43 & & 42.4 \\
\hline そ の & 他 & 47 & & 40.1 & 57 & & 39.2 \\
\hline
\end{tabular}

註）通産省：「工業用地統計表」1963，より作成。

は，最小值 $8.8 \%$ (石油製品・石炭製品製造業) の約 22 倍に達して特り，中京の 場合（ただし愛知県）について見ても，同じく前者の最大值 $194 \mathrm{~m}^{2}$ (鉄鋼業) は, 
最小值 $18 \mathrm{~m}^{2}$ （出版・印刷・同関連産業）の約 11 倍, 後者の最大值 $97.0 \%$ (出版・ 印刷・同関連産業）は，最小值 $21.7 \%$ （パルプ・紙・紙加工品製造業）の約 4.5 倍に 及んでいるのである。この事例からもらかがわれるよらに，敷地規模と容積率 は業種別に見ても逆の相関関係にあり，從業者 1 人当り敷地面積の大なる部門 は容積率が小さく，従業者 1 人当り敷地面積の小なる部門は容積率が高い。す なわら全国の場合，容積率が平均を上廻る「食料品製造業」「「繊維工業」・「衣 服その他の被維製品製造業」·「家具装備品製造業」·「出版・印刷・同関連産 慈」・「ゴム製品製造業」・「皮革・同製品製造業」·「金属製品製造業」・「機械 製造業」·電気機械器具製造業」·「輸送機械器具製造業」·「計量器 · 湘定器 ·测量機械・医療機械・理化学機械・光学機械・時計製造業」·「その他の製 造業」等の13業種は，わずかに「輸送機械器具製造業」を唯一の例外としてい ずれも従業者 1 人当りの敷地面積では平均値を下迴っている。他方容積率に拉 いて平均値を下迴る「木材・木製品製造業」・「パプ・紙・紙加工品製造業」・ ·「化学工業」·「石油製品・石炭製品製造業」·「案業・土石製品製造業」·「鉄 鋼業」・非鉄金属製造業」の 7 業種はすべて從業者 1 人当りの敷地面積に抒い ては平均值を上迴っている。

中京 (愛知県) の場合, 第 1 グループ, 第 2 グループの業種に若干の変動があ

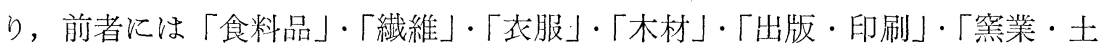
不」·金属製品」·電気機器」・「精密機器」・「その他」の10部門，後者には 「家具・装備品」・「パルプ・紙」・「化学」・「石油・石炭製品」・「ゴム製品」・ 「鉄鋼」·「非鉄金属」·機械」・輸送機械」の9 部門が各々分類される。(愛知県 の場合「皮革・皮革製品」，は除外する)。ただし第 2 のグループに属する「家具・ 装備品」のみ愹積率が平均を僅かに下迴るとともに, 従業者 1 人当りの敷地 面積でも平均值を下迴る唯一の例外となっている。

いずれにしてもこのように敷地規模と建築密度の相関から各業種を二つのグ ループに分けた場合，その土地利用密度ないしは強度は前者のグループに和い てより高く，後者のグループは相対的により低いと見ることができる。従っ て, 前節で見た敷地規模 ・ 建築密度の 地域差は, 各々の地域の工業構成の相 違, 大まかに言觉ば第 1 のグループを主とする工業構成であるか, 第 2 のグル 一プに偏った工業構成であるかによって左右される面が少くないと思われる。 何故ならば，集積度の高い地域においては，その位置価值に相応した高い土地 利用密度を保持するため, 必然的に第 1 のグループの工場をより多く立地せし め, 相対的に低い土地利用強度の第 2 のグループの業種の工場は, 第 1 のグル 一プの工場との立地獲得競争に打くれをとって，位置価值のより低い，従って 
集積度のより低い地域に立地することとなると考光られるからである。かかる 点を検討するために第 7 図 (全国)，第8 図 (中京) を作成した。これらの図に

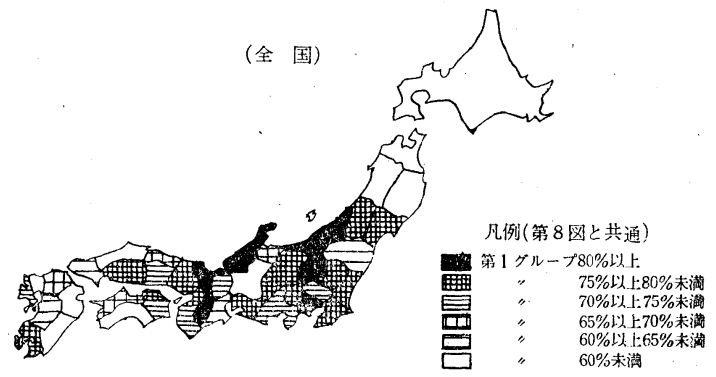

第 7 図 前 1 グループの工場の割合

注）通产省：「工業用地統計表」1963，より作成

は各地域の工場数全体 （ただし従業者30人以上） に占める第 1 のグループ の工場の割合が示されて いる。従って前述の予想 からすれば集積度の高い 地域に执いては第 1 グル ープの工場の割合が高く, 集積度の低い地域ではこ の割合が低くあらわれて 来るはずである。先ず第

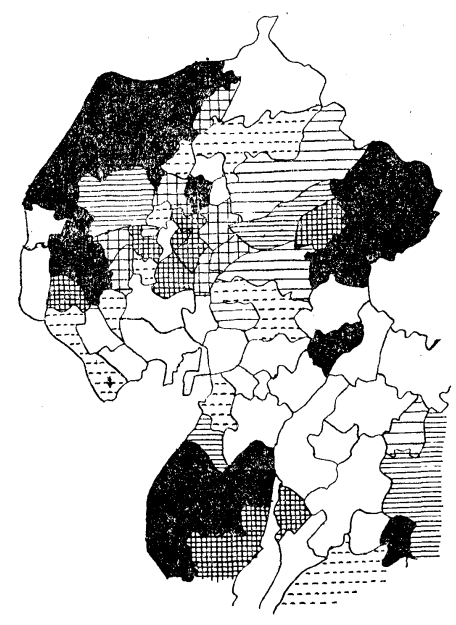

第 8 図 第 1 グループの工場の割合

註）愛知県統計課資料より作成。
7 図 (全国) の場合から自よら。

この図で第 1 グループの工場の割合が 80 \%を超光るのは新潟・群馬・東京・石川・ 福井・京都・奈良の 8 都府県であるが，こ れらのらち第 3 節のIー、に属するものは 東京都のみ， $I$ そしてIIーBが群馬・石川の 2 県，他はい ずれもIII一bに属する諸県である。これら に次いで第 1 グループの工場の割合が大き い宮城・山形等14府県について見ても，I 一 、 に属する多のは神奈川・愛知・大阪の 3 府県, $I$ 一 $\mathrm{b}$ 属与るものは兵庫・広息 の 2 県であり，他はII-B (香川), III(宮城・茨城·千葉), III-b (山形・栃木·長 野・山梨・鹿児島) 等となっている。すなわ ち集積度の高い地域の多くは第 1 グループに偏った工業構成を示していると言 らことができようが，その逆は必ずしも成立せず，第 1 グループに偏った工業 構成を持らながら集積度の低い府県も少くない。もっともここにめげたIIーB， III一 $\mathrm{a}$ ，III一bの諸県のなかには前揭第 5 㘠に拈いて例外的に(1)，(等に分布 していた奈良・石川・福井等が含まれて和り，これらについては前にも指摘し たごとくさらに歴史的な考察によって敷地規模・建築密度等の特性が吟味され 
ねばならないが，その他はの，そして多くがきに分布する諸県であり，これら の場合には第 1 グループの工場が多いにもかかわらず，それらの敷地規模が必 ずしも小さいとは言えず，建築密度もまた必ずしも高いとは言い難いことを暗 示している。

このよらな事情は中京についても同様である。第 1 のグループの工場の割合 が全体の $80 \%$ こ学る18市町村のうち，I一bは瀬戸市・一宮市・木曽川町・ 尾西市，II-Bは江南市・常滑市，これに対しIII一 織町 ·津島市 ·東浦町, III- b は長久手村 · 扶桑町 ·師勝町 · 知多町 · 阿久比 町・東郷村・六ツ美村等多数にのぼっている。な抗この場合 I一 $\mathrm{a}$ ， II - A 等 の地域は存在しない。さらにこの割合が75\%をこえる 9 区市町村について見て も，I- - の西区：中村区， I-bの旭町，II-Aの西枇杷島町， II - B の高 浜町の外は，比較的集積度の低い甚目寺町（III-a)，半田市（III-a)，佐屋町 (III-b) 等であり，第 1 グループの工業の卓越しているのは必ずしも集積度の 高い地域のみに限定されてはいない。

これらの事実は，本来，あるいは相対的な意味に和いて，小敷地規模・高建 築密度を特性とし，傾向として高集積度の地域に立地する確率の高い第 1 グル 一プの諸工業といえども，それが仮りに低集積度の地域に立地した場合には比 較的大敷地規模・低建築密度を示し，逆に，本来，あるいは相対的に大敷地規

（I 全国）
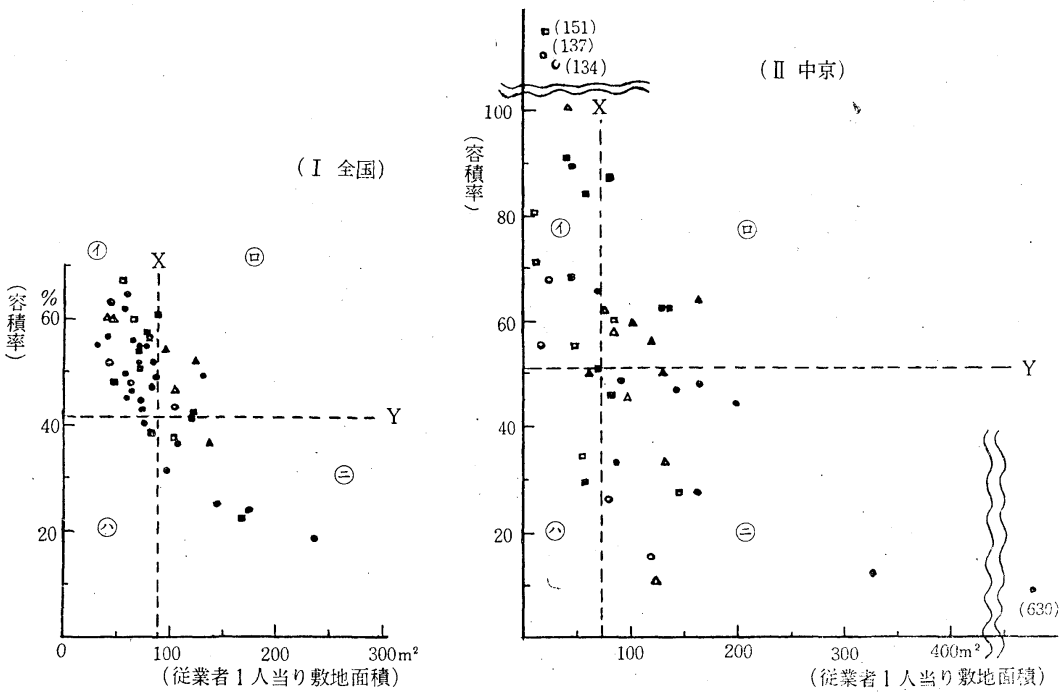

第 9 図食料品製造業の敷地規模と建築密度 
模・低建築密度を特性とし, 傾向として低集積地域に立地する確率の高い第 2 グループの諸工業といえども，それが仮りに高集積度の地域に立地した場合に は比較的小敷地規模・高建築密度を示すことを予想させる。このよらな予想を 検討するために，第 1 グループ・第 2 グループの諸工業のなかから二・三事例 を選び，第 9 図 (食料品)，第10図 (繊維)，第11図 (機械)，第12図 (鉄鋼)，第13 図 (化学) 等を作成して見た。紙数の都合上各々についての詳述は避けるが, 全国の場合, 中京の場合とも第 2 表のごとくょり左上に分布するのは I-

(I 全国)

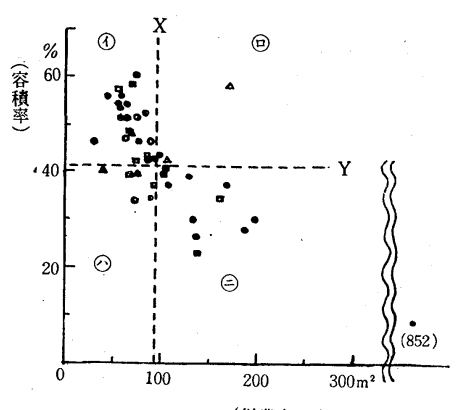

(従業者 1 人当り敷地面䅡)

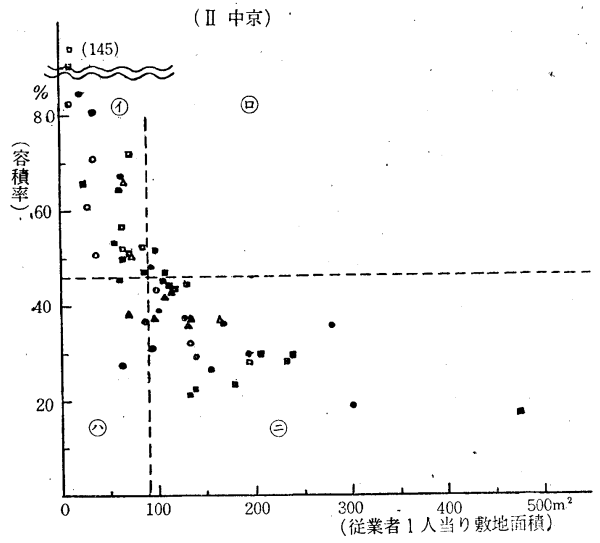

第10図 繊維工業の敷地規模と建築密度
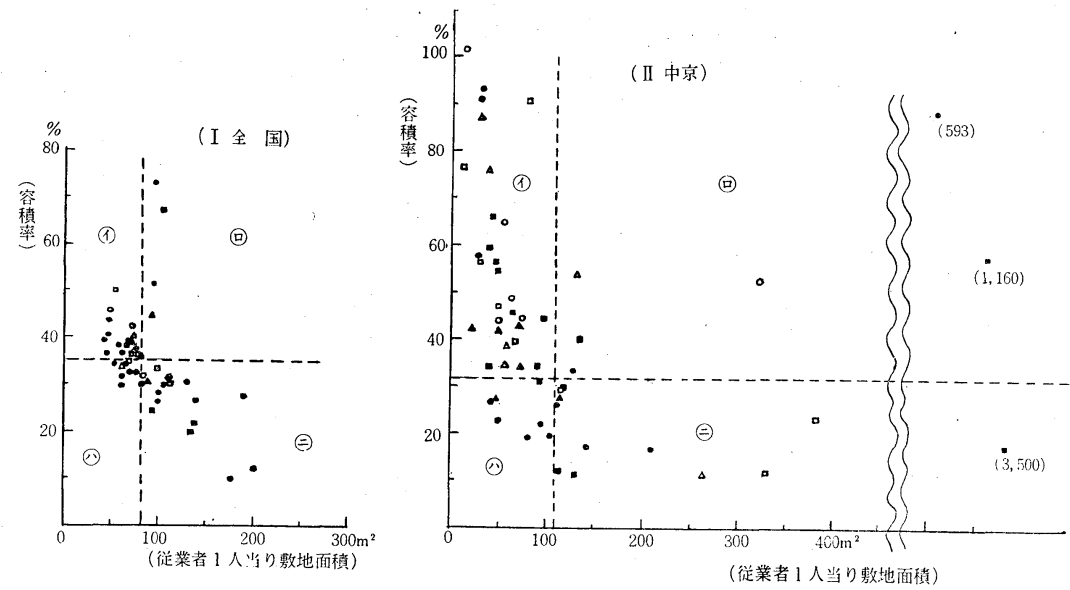

第11図 機械製造業の敷地規模と建築密度 
第 2 表 主要業種に括ける敷地規模・建築密度と集積度との関係

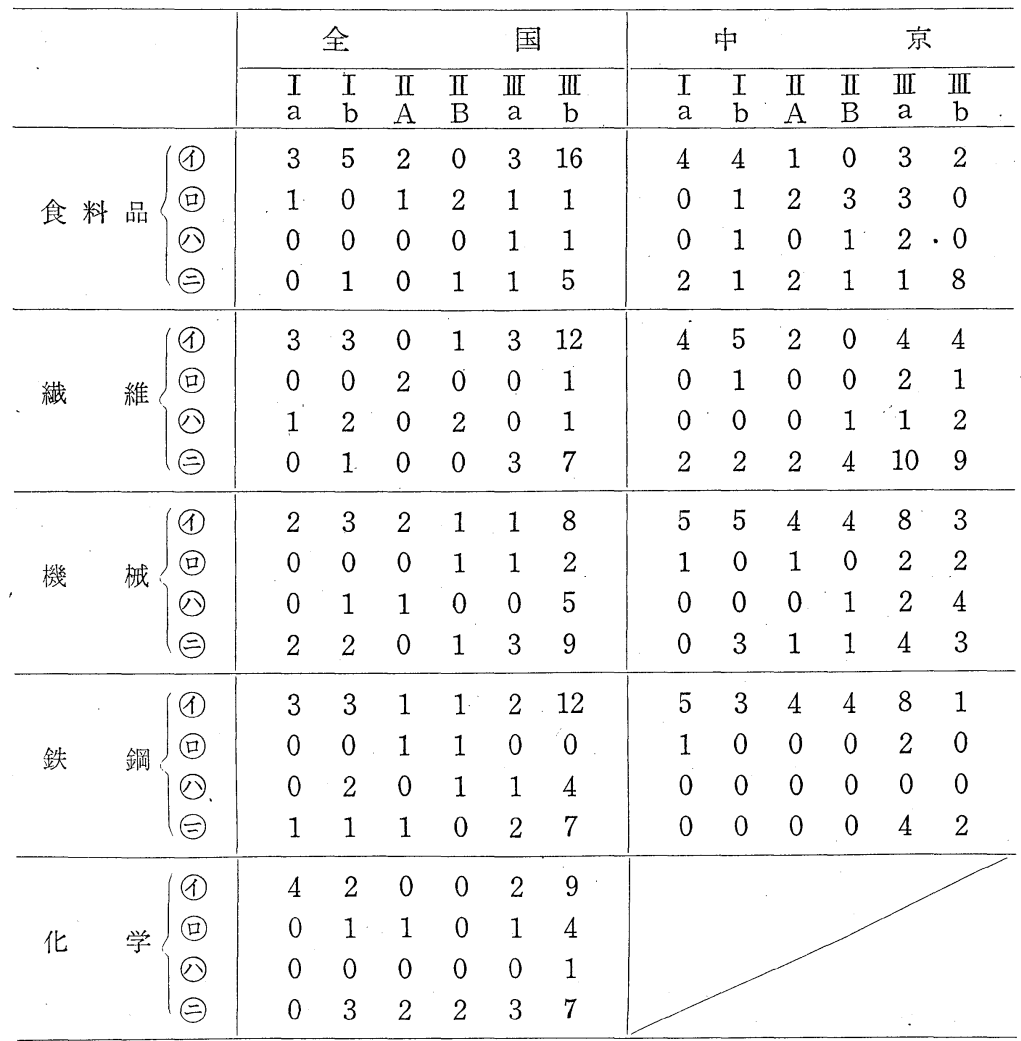

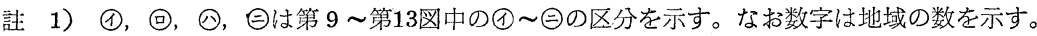

2） I a I I b ……II b は第 1 ，第 2 図の区分を示す。

3）各欄の地域の合計は業種により該当する工業のない場合もあるため一致しない。

4）第 9 ～第13図より作成。
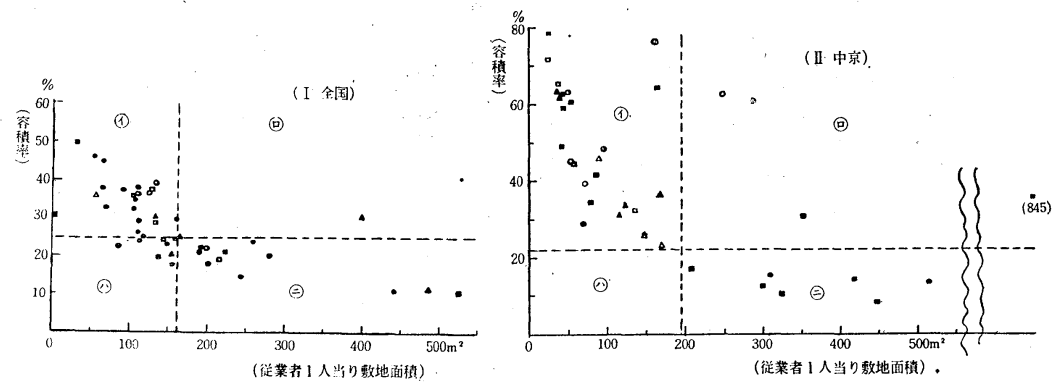

第12図 鉄鋼業に招ける敷地規模と建築密度 


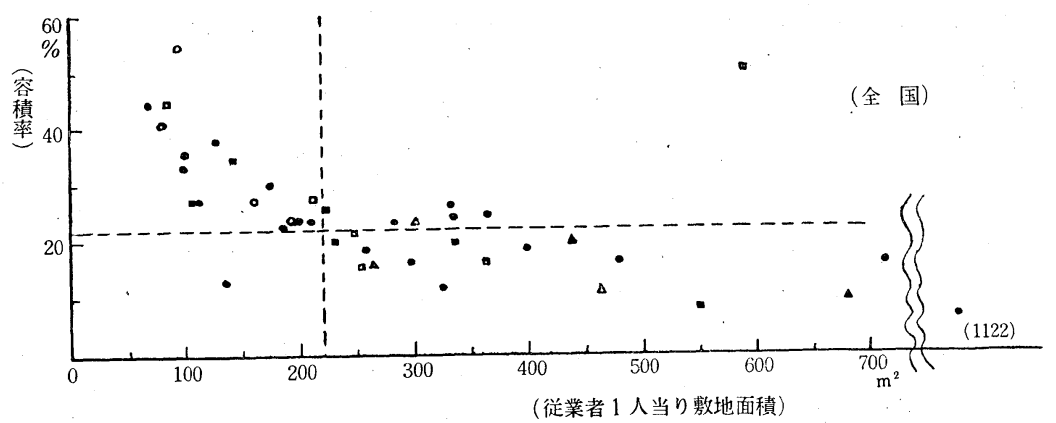

第13図，化学工業の敷地規模之建築密度

$\mathrm{I}$ 一 $\mathrm{b}$ 等集積度の高い地域であり，より右下に位置するのは概して III- $a ， I I I$ - $\mathrm{b}$ 等集積度の低い地域であることがわかる。しかも平均值を中心としての左 上 (小敷地規模・高建築密度), 右下 (大敷地規模 - 低建築密度) への分散の程度は第 1 のグループの場合比較的小さく, 立地の如何によって敷地規模・建築密度に それ程大きな差がないことを物語っているのに対し，第 2 のグループの場合， それらの地域的な格差はかなり大きい。そしてこのような第 1 グループ・第 2 グループによる性格の相異は中京の場合よりもむしろ全国の場合一層はっきり した形で現机て抢り，また，全国，中京を問わず重化学工業の場合とくに顕著 であることがわかる。

\section{5 む す び}

以上，原単位としての工場の敷地規模・建築密度等を，とくにその地域的特 性の吟味という点に中心を置いて考察してきたが，それら性ともに工業に拈汁 る土地利用強度ないしは密度の表現形態とも見なされるものであるから，土地 利用強度ないしは密度に地域差が存在すれば当然地域的に異った值を取るわけ である。ところで土地利用強度ないしは密度は，春日茂男によって明かにされ たごとく位置の価值に相応して様々に変化するが，それは近似的には工業集積 の度合之密接な関係があり, その度合が相対的に最高の地点・地域に和いて最 高の土地利用強度を，そしてその度合が周辺に向って漸減するに伴って順次低 落した土地利用強度を示す。工場の敷地規模・建築密度等もこのような集積度, 従って土地利用強度の変動に伴って変化し, その度合の高い地点・地域にあっ ては小敷地規模 ·高建築密度が，その度合の低い地点・地域にあっては大敷地 規模・低建築密度が一般的となると言光よう。しかも土地利用強度は業種によ ってかなりの格差が見られるため, 集積度の高い地域にはより小敷地規模, よ 
り商建築密度の業種が，集積度のより低い地域にはより大敷地規模，より低建 築密度の栄種が卓越する。と同時に，同一業種の工業について見ても，地域の 集積度の高低に応じて土地利用強度に地域差があり, 集積度の高い地域に立地 する工場は集積度の低い地域に立地するものに比べて敷地規模が小さく建築密 度が高い。しかもこのような同一業種内での地域差は，相対的に土地利用強度 の高い業種の場合比較的小さく，それが低い業種の場合概して大きい。これら のことからきわめて大胆に工業的土地利用の地域的特性を模式化すれば第14図 のごとき構図が考光られよら。もちろんその当否については今後の検討にま去 ね将らないが，一応前揭の第 9 図，第10図，第11図，第12図，第 13図等とも相通ずるものがあらら。 もっとも以上に要約したよらな 工業に和ける土地利用の関係は,

「都市的土地利用に和いては特に 建造物の耐久性が条件の変化に対 して即時的な適応を困難ならしめ ている」ことが一因ともなって， 必ずしも明確・整然たる形で現わ れてはいない。そこには多くの例

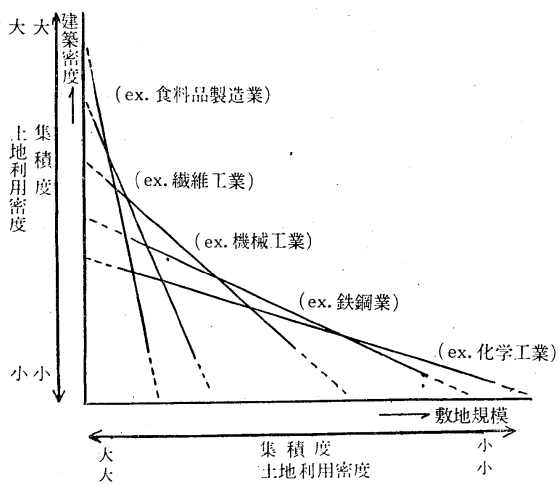

第14図工業的土地利用の模式

外もあり，分析の不手際に基く混乱も少くないが，一応地域をマク口（全国的 に見た場合の大都市圈と国土の周辺地域）にとっても，ミク口（大都市圏一中京一に 扣けるとの核心部分と外縁地域）にとっても涪ぼ類似した結果の得られたことを 報告して筆を特く。

: 本稿は昭和38年度文部省科学研究費による研究成果の一部であり, 昭和38年10 月, 日本地理学会大会に抢いて報告した要旨をもとにし，若干加筆修正を加えたもの である。研究遂行に当って御指導, 御助言を晹った名古屋大学松井武敏教授, 井関弘 太郎助教授, 大阪市立大学春日茂男助教授に厚くお礼申し上げる。また資料の蒐集に 際してお世話になった愛知県統計課工業統計係の諸氏, 並びにその整理に御協力下さ った大分大学助手船橋泰彦氏に深謝の意を表する次第である。なお文中敬称は省略さ せて頂いた。

\section{【註】}

1）絊野昭：工場建設のレィアウト，通 産省企業局工業立地指導室編「工業立 地」, 昭36，第10章， p 237

2）たとえば通産省：「工業用地統計表」 1963, 井関弘太郎：地域計画の為の基
礎的知識，人文地理 16 巻 3 号， p 79な ぞ。

3）伊藤通畦：都市の生態と計画，技報 堂，昭36， p 253。なお紨野：前揭 書, は容積率について臨海の装置工業 で15\%，機械工業で25\%，内陵では平 
均30〜35\%とい5数字をあげている ( p 241)。

4）通産省：前掲工業用地統計表。

5）井関：前揭論文 p 79

6）春日茂男：工業的土地利用の生産性 について, 人文研究第 14 巻第 10 号, 昭 $38, \quad \mathrm{p} 34$

7）春日：前掲論文

8）春日：前掲諭文

8）春日：前掲論文, p 33

9）春日：前掲論文, p 32

10）春日：前掲論文, p 32

11）西岡久雄：工業集積に関する覚書一 特に集積測定法について一，青山経済 論集第14巻第 4 号, 1963, に教兄られ る所が多かった。

12）全国の場合内水面積を除いた各都道 府県の面積が, 中京の場合山林面積を 除いた各区市町村の面積が基準とされ

$$
\text { ている。 }
$$

13）たとえば前掲工業用地統計表より 1 事業所当りの敷地面積と従業者 1 人当 りの敷地面積を規模別に求めるならば 次表のごとくである。

\begin{tabular}{|c|c|c|}
\hline 従業者数 & $\begin{array}{l}1 \text { 事業所当り } \\
\text { 敷地面積 }\end{array}$ & $\begin{array}{l}\text { 従業者 } 1 \text { 人当 } \\
\text { り敷地面積 }\end{array}$ \\
\hline $30 \sim 49$ 人 & $28100 \mathrm{~m}^{2}$ & $74.5^{\mathrm{m}^{2}}$ \\
\hline $50 \sim 99$ 人 & 48 & 69.5 \\
\hline 100～199人 & 112 & 81.5 \\
\hline 200〜299人 & 236 & 94.9 \\
\hline 300 499人 & 450 & 118.1 \\
\hline 500 999人 & 1,025 & 149.0 \\
\hline 1000 人以上 & 2,892 & 126.7 \\
\hline
\end{tabular}

14）緗野：前掲書 $\mathrm{p} 241$

15）春日：前掲論文 $\mathrm{p} 33$

(名古屋市立大学助教授)

\section{On the Relationship between the Location of Factories, and the Scale of Factory Sites and Density of Buildings}

by Kie ITO

This article is a consideration of the relationship between the location of factories, and the size of factory sites (expressed in terms of the area of factory site per employee), and density of buildings (where the index of site capacity=amount of built-up area/site area). The article examines the occurrence of this relationship throughout Japan, and in the Chukyo urban Zone (the city of Nagoya and its surrounding towns and villages), and is an attempt to clarify the regional differentiation of land-use in industry.

This type of factory-site-built-up area relationship differs greatly according to the usually-used industrial categories. This is because the layout of each type of factory differs according to the construction of the particular type of factory involved. However, in so far as there are regional differences in the condition of land as a productive element, there must also be regional differences in the degree of land-use. In other words, there is an obvious difference in the size of site-density of buildings measurement between factories situated in large cities, where location conditions are favourable and elasticity of land supply is small, and the factories which are located in the fringe-areas of the country where location conditions are 
poor and elasticity of land supply is high. It is proposed that a similar difference exists between factories located in the heart of an urban zone and factories located ini the outskirts of the zone.

Supposing that, as a relative index of location conditions, we use the extent of factory accumulation, as calculated from the correlation of the number of factories per area of a given region with the value-added production per unit area, then the following areas will emerge as areas exhibiting a high degree of density :

For Japan as a whole :-Tokyo, Kanagawa, Aichi, Osaka, followed by Saitama,

Shizuoka, Kyoto, Hyogo, Hiroshima and other administrative areas.

For the Chukyo area :-Higashi ku, Nishi ku, Naka ku, Mizuho ku, Atsuta ku,

followed by Kita ku, Nakamura ku, Showa ku and Minami ku (The above ' $k u$ ' are urban (administrative) districts of the city of Nagoya.), the cities of Ichinomiya, Seto, and Bisai and the towns ('cho') of Shinkawa, Asahi and Kisogawa.

Then, if we use statistics taken from the Industrial Site Survey of December 1961 to indicate the density of buildings and the scale of the sites of factories situated in the aforementioned areas, we find that the scale of sites is generally smaller, and the density of buildings is higher than in the case of factories situated in other areas.

From these results, we can say that the degree of factory site-use in areas where location conditions are favourable and the extent of accumulation is high is greater than site-use in areas where location conditions are poor and the extent of accumulation is low.

From this regional differentiation in site-use, two types of mutually intertwined phenomena seem to emerge :-

1) In areas of high accumulation, the following types of factory, which show a strong natural tendency to occupy small sites and densely built-up areas occur most frequently :-Food and provisions, Textiles, Clothing, Furniture, Printing and publishing, Rubber and rubber products, Leather products, Light metal products, Machinery etc., whereas factories where the occupance of large sites with a low degree of building density is a strong characteristic are more common in the following groups :Timber products, Paper and pulp, Chemicals, Oil and coal products, Ceramics and pottery products, Iron and steel, Non-ferrous metals, etc.

2) Taking industry as a whole, when factories are located in areas with a high degree of industrial concentration, there is a strong tendency for factories within the same industrial category to occupy small scale sites with a high built-up area density. 